\title{
The Effects of Rural Tourism on Sustainable Livelihoods (Case Study: Lavij Rural, Iran)
}

\author{
Jamal Kheiri ${ }^{1} \&$ Banafsheh Nasihatkon ${ }^{1}$ \\ ${ }^{1}$ Faculty of Management, University of Tehran, Tehran, Iran \\ Correspondence: Jamal Kheiri, Faculty of Management, University of Tehran, Tehran, Iran. Tel: 98-911-222-6945. \\ E-mail: jamalkheiri@ut.ac.ir
}

Received: October 16, 2015

Accepted: April 12, 2016

Online Published: June 5, 2016

doi:10.5539/mas.v10n10p10

URL: http://dx.doi.org/10.5539/mas.v10n10p10

\begin{abstract}
Using a quantitative methodology and questionnaire, this study sought to evaluate the impacts of tourism on sustainable livelihoods of local people of Lavij rural in Iran. Data collected from 230 local residents of the study area were analyzed using Pearson's correlation and linear regression. The results show that rural tourism has been able to play an effective role in sustainable livelihoods of people and there is a significant relationship between the development of rural tourism and sustainable livelihoods in Lavij. Rural tourism can predict a high percentage of changes in people's livelihoods sustainability. Therefore, with a proper planning, rural tourism can be used to development of sustainable livelihoods, quality of people's lives, job opportunities and poverty reduction.
\end{abstract}

Keywords: rural tourism, sustainable livelihood, Iran, lavij

\section{Introduction}

Agriculture could not be considered as the main source of income for rural livelihood anymore (Forstner, 2004). Agricultural income in rural areas are declining in all around the world even in the developed countries such as the United States of America (Fleischer \& Pizamt, 1997). This idea has been approved in developing countries that people who live in rural areas should adopt different strategies to make money. Among the various options, tourism is considered as an important tool for economic diversification (Binns \& Nel, 2002; Rid, Ezeuduji, \& Pröbstl-Haider, 2014; Jennifer Briedenhann \& Wickens, 2004; Dernoi, 1991). In this regard, rural tourism can be a direct way to engage indigenous people, a sales channel for their traditional products and crafts (Rid et al., 2014) and create jobs for all members of the family (Bhandari, 2013).

The definition of rural tourism is emphasized that local people should be benefited, entrepreneurship is small-scaled and managed by the local community (Park \& Yoon, 2009; Reichel, Lowengart, \& Milman, 2000). In many parts around the world, development of tourism includes family-oriented SME (Note 1) s (Getz \& Carlsen, 2000, Fleischer \& Pizam, 1997, Mendonsa, 1983). Therefore, economic and social development should significantly improve the local people's livelihood (Friedman, 1992). Local hosts have a major impact on the rural tourism success because they can attract a large number of tourists. Consequently, money is coming into the village and it contributes economic development and increase people's incomes (Fotiadis et al., 2016, Bosworth \& Atterton, 2012).

Rural tourism is dependent on natural geography and ethnic features of a village (Guzman-parra, Quintana-garcía, Benavides-velasco, \& Vila-oblitas, 2015). In the whole world, developing countries enjoy rich resources based on their pristine natural landscape and cultural treasures. These are their competitive advantages to attract tourists to provide a new experience (Wahab, 1974, p. 15). Middle East is one of these areas where the most countries there have a rich culture and ancient history. However, development of rural tourism has been ignored in this region but Israel (Ghaderi \& Henderson, 2012, Fleischer \& Pizam, 1997). Iran is one of those countries that enjoy plenty of resources for promoting rural tourism (Kheiri, Zeinabad, \& Tabatabaie, 2016).

Iran's villages have a lot of beauties to offer visitors such as Indigenous houses, local cuisine, folk costumes, beautiful pristine landscape, lush nature and rich culture are the physical attractiveness and rural culture. But these potentials had not been used properly, and little research has been done on rural tourism and its effect on local's livelihood in Iran (Ghaderi \& Henderson, 2012). The aim of this research is to fill this gap by the 
studying of rural tourism and its impact on the sustainability of the indigenous people's livelihoods in Lavij rural in Mazandaran Province, Iran.

\section{Literature review}

Rural tourism is a type of tourism, which takes place within the village (Ghaderi \& Henderson, 2012). This definition has been provided by the European Community as well (Farmaki, 2012). This type of tourism by diversifying the economic structure of rural people, makes locals less vulnerable to sudden changes in the agricultural market (Fotiadis et al., 2016). For a long time, tourism has been a tool for rural economic and social development (Maloletko et al., 2015), in particular, for those who suffer from declines in agricultural activities (Iorio \& Corsale, 2010). It is also being seen as an alternative for mass tourism (Guerrero, Valdez Pérez, \& Ibarra, 2013; Ghaderi, 2004; Sharpley, 2000). Wilson (2001) argued that development of rural tourism is easier in comparison to other development strategies and it has lower costs as well (Jaafar, Bakri, \& Rasoolimanesh, 2015). Encouraging rural tourism is a policy which is used not only in developed countries but in developing countries (Iorio \& Corsale, 2010). In the 1990s, when various events of last decade led to high unemployment in rural areas of Eastern Europe (Abinama \& Jafari, 2015), tourism was recognized as an activity that could accelerate economic growth, adapting to underdeveloped regions and improve the living standards of local communities (Jenny Briedenhann \& Wickens, 2004). In less-developed countries of Africa, where are faced with poverty in rural areas (Bidoki \& Kargar, 2016), tourism is one of the few options for rural development (Evans \& Ilbery, 1989; Getz, 1983; Marsden, 1992).

Rural tourism as a means of sustainable rural development is widely accepted throughout the world (Kim \& Jamal, 2015). Sustainable Development Approach, is the link between economic, environmental and social issues in rural tourism (Garrod, Wornell, \& Youell, 2006). Mbaiwa \& Kolawole (2013) claim that local people are the centrality of sustainable livelihoods.

Jennifer Briedenhann \& Wickens (2004) argue that it is very important to mention that if a country wants to make a profit as much as possible in rural tourism and make it less harmful, it must have coordination with the socio-cultural lifestyle of indigenous people. However, it should be evaluated for each region whether tourism has profit or even loss (Binns \& Nel, 2002). What is expected from tourism is to play a major role in the revitalization of rural areas and bringing high profits to the local community (Iorio \& Corsale, 2010; Silva \& Leal, 2015). Tangible benefits for livelihood help local community to choose a tourism program (Ashley, 2000).

Table 1 shows some of the past researches on rural tourism and local people livelihoods.

Table 1. Rural tourism in the literature

\begin{tabular}{|l|l|l|}
\hline Author/s/Year & Research topic & Results \\
\hline $\begin{array}{l}\text { Turnock } \\
(1990)\end{array}$ & $\begin{array}{l}\text { Tourism in Romania: Rural } \\
\text { planning in the Carpathians }\end{array}$ & Showed opportunities for women in rural areas \\
\hline Place (1991) & $\begin{array}{l}\text { Nature tourism and rural } \\
\text { development in Tortuguero }\end{array}$ & $\begin{array}{l}\text { Few of the villagers were aware of the economic } \\
\text { value of the park based tourism, no systematic } \\
\text { attempt to promote tourism in rural areas }\end{array}$ \\
\hline $\begin{array}{l}\text { Luloff et al. } \\
(1994)\end{array}$ & $\begin{array}{l}\text { Assessing rural tourism efforts in } \\
\text { the United States }\end{array}$ & Identified characteristics of the US 50 States \\
\hline $\begin{array}{l}\text { Oppermann } \\
(1996)\end{array}$ & $\begin{array}{l}\text { Rural tourism in Southern } \\
\text { Germany }\end{array}$ & $\begin{array}{l}\text { Several aspects of rural tourism have been } \\
\text { discussed, the main market segment is families } \\
\text { with children }\end{array}$ \\
\hline $\begin{array}{l}\text { Reichel, } \\
\text { Lowengart, \& } \\
\text { Milman } \\
(2000)\end{array}$ & $\begin{array}{l}\text { Rural tourism in Israel: Service } \\
\text { quality and orientation }\end{array}$ & $\begin{array}{l}\text { Management and marketing implications for } \\
\text { service quality improvements are discussed along } \\
\text { with the acute need for appropriate training }\end{array}$ \\
\hline $\begin{array}{l}\text { Canoves et } \\
\text { al. (2004) }\end{array}$ & $\begin{array}{l}\text { Rural tourism in Spain: An analysis } \\
\text { of recent evolution }\end{array}$ & $\begin{array}{l}\text { Identified differences in the pattern of evolution, } \\
\text { women part is important }\end{array}$ \\
\hline León (2007) & $\begin{array}{l}\text { The impact of tourism on rural } \\
\text { livelihoods in the Dominican } \\
\text { Republic's coastal areas }\end{array}$ & $\begin{array}{l}\text { Personal and community characteristics, such as } \\
\text { knowledge of a second language, young age, and } \\
\text { predominance of domestic and day-trip tourism } \\
\text { are the most important factors in determining } \\
\text { tourism-related employment }\end{array}$ \\
\hline
\end{tabular}




\begin{tabular}{|l|l|l|}
\hline $\begin{array}{l}\text { Möller } \\
(2012)\end{array}$ & $\begin{array}{l}\text { Gendered entrepreneurship in rural } \\
\text { Latvia: Exploring femininities, } \\
\text { work, and livelihood within rural } \\
\text { tourism }\end{array}$ & $\begin{array}{l}\text { Women's entrepreneurship within rural tourism in } \\
\text { Cesis district have been evaluated }\end{array}$ \\
\hline Zhou (2014) & $\begin{array}{l}\text { Online rural destination images: } \\
\text { Tourism and rurality }\end{array}$ & $\begin{array}{l}\text { Evaluated online image of a rural tourism in china, } \\
\text { found three themes: resources, rewards and } \\
\text { expectations }\end{array}$ \\
\hline $\begin{array}{l}\text { Li, Ryan, \& } \\
\text { Cave (2016) }\end{array}$ & $\begin{array}{l}\text { Chinese rural tourism development: } \\
\text { Transition in the case of } \\
\text { Qiyunshan, Anhui. -2008-2015 }\end{array}$ & $\begin{array}{l}\text { Chinese rural tourism policies have been described } \\
\text { in Daoist village }\end{array}$ \\
\hline
\end{tabular}

More than 21 million people in Iran (about 26 percent of Iran's 79 million population) live in rural areas in 2016 (Iran's Statistics Centre, 2016). Migration from rural to urban areas has been one of the major social problems in Iran in recent years. Iran's urban population grew from 34 percent in 1956 (Analysis of urbanization and internal migration situation in the Islamic Republic of Iran, 2012) to 74 percent in 2016 (Iran's Statistics Centre, 2016). Between 2007 and 2012, more than four million and three hundred thousand people immigrated from Iran's villages into urban areas, i.e. 77\% of all immigrants (Iran's domestic migration, 2011). It caused declining in agricultural products as well. Between 2003 and 2014, the area of agricultural land in Iran declined 6 percent (Detailed results of the general census of agriculture, 2013). Lack of a sustainable income has been the main reason for this situation. Economic factors such as unemployment, poverty and low income were the focal reasons for 55\% of migration from rural to urban areas in Iran (Ghasemi Ardahani, 2006). The process of migration from the countryside into the city is very critical and measures should be taken to more people stay in rural areas. In traditional business practices in rural areas, all family members were helping and involved. It is necessary to the replacement option to be such a case. In this regard, tourism is the best choice in these areas (Mcareavey \& Mcdonagh, 2011; Park et al., 2012).

But there are some gaps and little known about implementing the policies about promoting sustainable livelihood, especially in small scales (Addinsall et al, 2015; Christensen \& Mertz, 2010). Despite widespread acceptance in the family-based businesses in rural tourism, there has been little research about it (Getz \& Carlsen, 2000). Studies of farm exit or livelihood transition are almost entirely absent in poor rural agrarian contexts of developing countries (Bhandari, 2013). The same gap can be seen in studies about Iran's rural tourism (Ghaderi $\&$ Henderson, 2012). The aim of this study is to investigate the sustainability of livelihoods and rural tourism in Iran and provide solutions for its development.

\section{Tourism in Iran}

Iran is a large country in the Middle East with nearly 80 million population and 1.65 million square meters. Nineteen cultural monuments of Iran are in the list of UNESCO (UNESCO, 2016) while its history dates back to 7000 years ago. The main organization which is responsible for management of tourism in Iran is Cultural Heritage, Handcrafts and Tourism Organization (ICHTO). The nation has a diverse climate where can be swam in southern coast and can be skied in the highlands of north and west at the same time. The pristine forested area of northern Iran is one of the most fantastic natural areas in all around the world. Iran has a variety of ethnics, languages and traditions.

Despite all these sources, Iran hosted only 4.8 million tourists in 2014 while more than 3.5 million of them came from neighboring Iraq, Turkey, Azerbaijan and Afghanistan (Euromonitor, 2015). Additionally, a large number of them were the Iranians who live in foreign countries and came back to Iran during the year to meet their families and friends. Iran's tourism revenue from international tourists was only $\$ 1.3$ billion in 2013 (Tourism highlight, 2015 ) and its contribution to GDP was less than 2.5 percent in 2014 (Travel \& tourism economic impact: Iran, 2015).

Improper position of Iran's in international tourism has many reasons, such as the 8-year Iran-Iraq war from 1980 to 1989 , unfavorable destination image, International sanctions and ongoing tensions with Western powers (Ghaderi \& Henderson, 2012).

\subsection{The Case of Lavij Rural}

One of the most beautiful villages in Iran is Lavij. Lavij Rural District (Persian: دهنتان لاويج) is located in Chamestan District, Nur County, Mazandaran Province. This rural includes 16 villages, 12 inhabited and three uninhabited. Its population is around 3500 (Moosa Dokht, 2013). The village has a total area of 95 square 
kilometers which 80 percent of this area covered by forest.

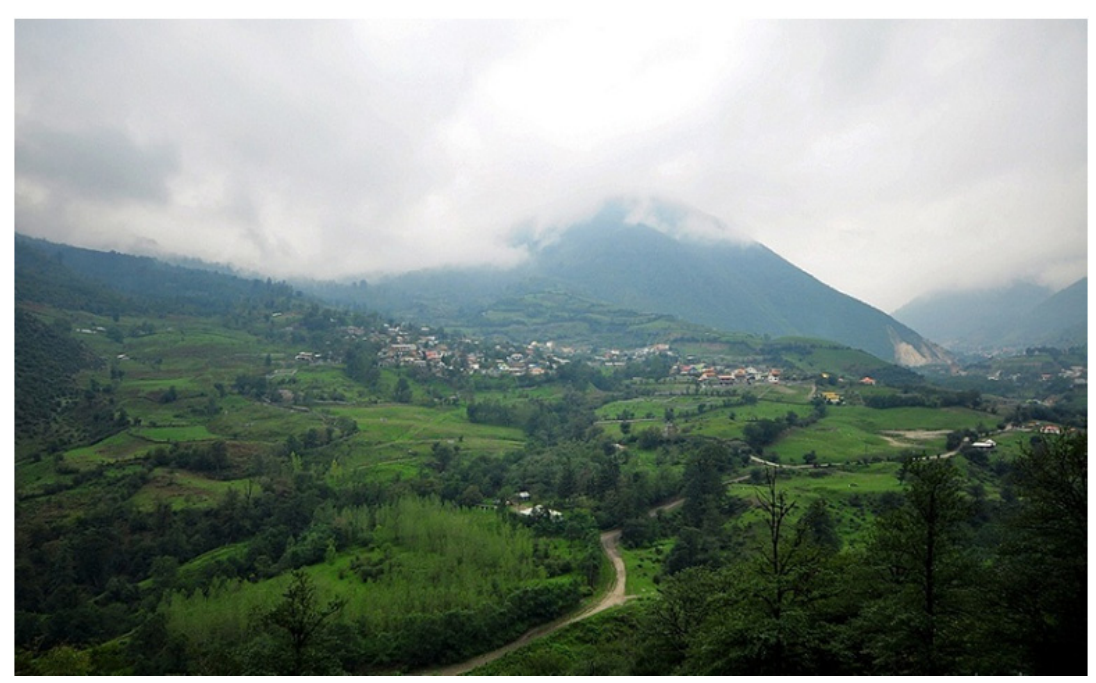

Figure 1. A view of Lavij rural

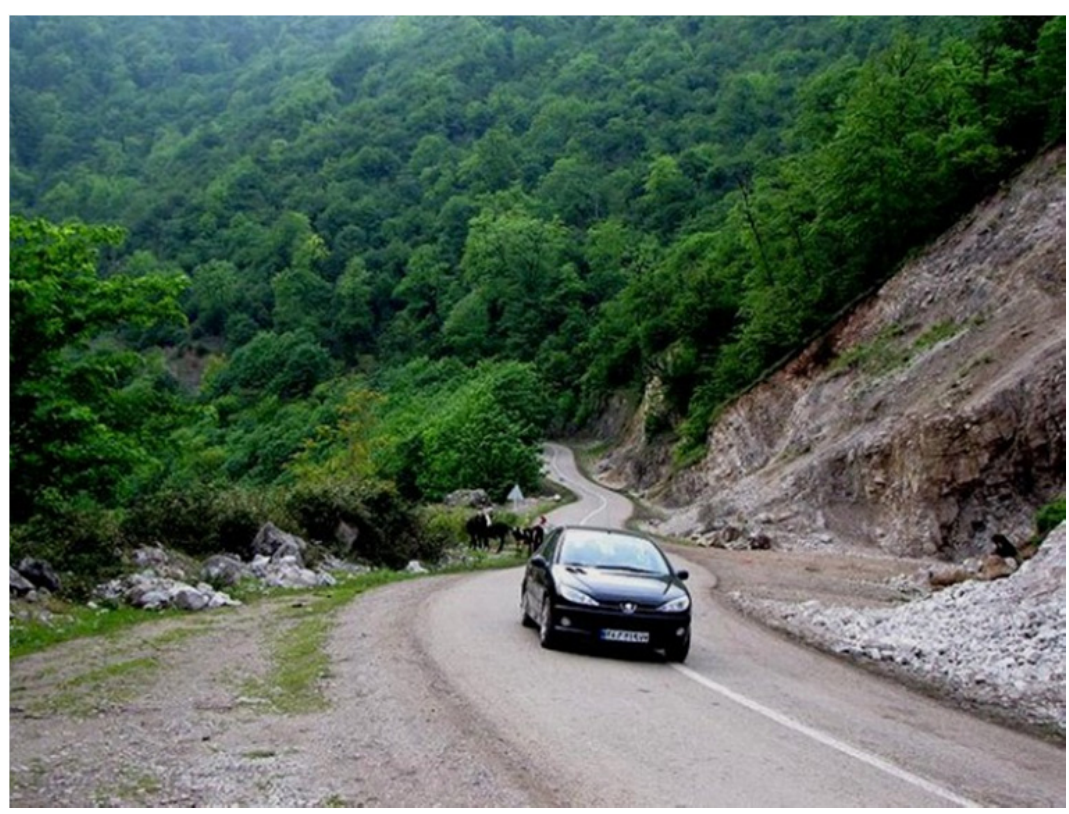

Figure 2. Lavij mountain road

Lavij is surrounded by Alborz Mountain. This area is always lush, beautiful and providing extraordinary landscape.

The main occupation of the village residents is agriculture, handicrafts and animal husbandry. Among Lavij's physical and cultural attractions rivers, waterfalls, hot and cold springs, forest areas and chalets, castles, shrines and Tir-Mah Sizdah Shab can be noted. 


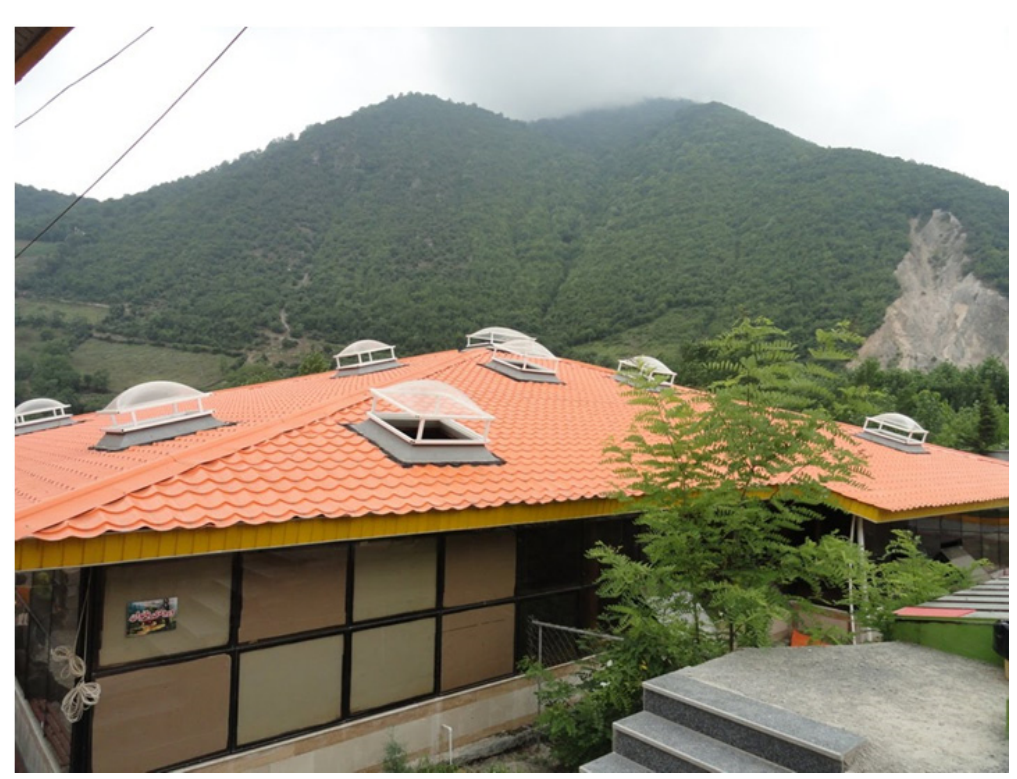

Figure 3. Lavij hot spring building

As it can be noticed this village has a major potential for rural tourism, but it has been neglected. That's why many residents have been migrated to cities in recent years and some of Lavij's villages have been nonresidential. Based on previous studies and the case study of this research the following hypotheses are proposed:

H1: Rural tourism development is effective on sustainable livelihoods in rural areas of Lavij.

$\mathrm{H} 2$ : There is a significant relationship between the development of rural tourism and sustainable livelihoods assets in Lavij rural.

H3: There is a significant relationship between rural tourism development and vulnerability of sustainable livelihoods in Lavij rural.

H4: There is a significant relationship between rural tourism development and rural economic structures of sustainable livelihoods in Lavij.

\section{Methodology}

The research method in this study is quantitative. Required information have been collected using two methods of library and field studies. In the library method, researchers has been tried to understand measures and concepts of rural tourism and sustainable livelihoods by studying fundamental research related to the topic. In the next step, these measures have been given to the experts to be validated. In the field study section, a questionnaire was used based on 5-point Likert type scale with "strongly disagree" at the lowest end and "strongly agree" at the highest end to assess the status of rural tourism and sustainability of livelihoods in the study area.

Lavij rural district has 16 villages where four villages are haunted and a total number of 3,500 people are living in the 12 villages (Moosa Dokht, 2013). 230 residents of these villages were selected by random sampling as the study's population. Of this number, 207 were male and 23 were female.

For data collection, a questionnaire was designed containing 59 questions. Nine questions were about the development of rural tourism (independent variable), and 50 questions were about the sustainable rural livelihoods in three sections which include assets, vulnerability and organizational structure (dependent variables).

Validity of the research was confirmed by experts who were familiar with the research subject. Cronbach's alpha was also used to measure the reliability of the research. The number of alpha for the development of rural tourism variables was $(0.706)$ and for sustainable livelihoods variable was $(0.863)$ which are acceptable. Every single aspect and any of the questions showed also appropriate alpha, indicating good internal consistency reliability of the questionnaire.

In this study, SPSS 22 software was used to analysis the data. For determining the normal distribution of data Kolmogorov-Smirnov test was used. Pearson correlation test, Spearman's regression analysis and path analysis 
also were used for measuring variables of the research.

\section{Results and discussions}

According to the study findings, the majority of the villages' residents are men, and that has been detected in the information extracted from the questionnaire as well. Ninety percent of respondents were male and 10 percent were women (Table 2). Over $60 \%$ of them were between 31 and 50 years old and less than 4 percent were over 60 years old. Nearly half of the rural population have a monthly income between 800 thousand to 1 million Tomans (Note 2) which is low-income and very close to the poverty line which is 745,000 Tomans (Iran's statistic center, 2015). Approximately 60 percent of rural residents lack a college education and 40 percent had a bachelor's or master's degree.

Table 2. Demographic profile of respondents

\begin{tabular}{|c|c|c|c|}
\hline Variables & & frequency & percent \\
\hline \multirow{2}{*}{ Gender } & Male & 207 & 90 \\
\hline & female & 23 & 10 \\
\hline \multirow{5}{*}{ Age } & $20-30$ & 43 & 18.7 \\
\hline & $31-40$ & 84 & 36.5 \\
\hline & $41-50$ & 60 & 26.1 \\
\hline & $51-60$ & 34 & 14.8 \\
\hline & More than 61 & 9 & 3.6 \\
\hline \multirow{4}{*}{ Education } & High school & 84 & 36.5 \\
\hline & Collage & 55 & 23.9 \\
\hline & Bachelor & 74 & 32.2 \\
\hline & Masters and higher & 17 & 7.4 \\
\hline \multirow{6}{*}{ Income } & $800,000-1,000,000 \mathrm{~T}$ & 104 & 45.2 \\
\hline & $1,000,000-1,200,000 \mathrm{~T}$ & 51 & 22.2 \\
\hline & $1,200,000-1,500,000 \mathrm{~T}$ & 38 & 16.5 \\
\hline & $1,500,000-1,700,000 \mathrm{~T}$ & 14 & 6.1 \\
\hline & $1,700,000-2,000,000 \mathrm{~T}$ & 20 & 8.7 \\
\hline & More than $2,000,000 \mathrm{~T}$ & 3 & 1.3 \\
\hline \multirow{5}{*}{ Occupation } & Farmer & 26 & 11.3 \\
\hline & Ranchman & 17 & 7.4 \\
\hline & Teacher & 141 & 61.3 \\
\hline & employee & 13 & 5.7 \\
\hline & Others & 33 & 14.3 \\
\hline overall & & 230 & 100 \\
\hline
\end{tabular}

For testing the normality of the data Kolmogorov-Smirnov test has been used. The results showed the data are normal (Table 3). So, parametric tests were used to analyze the data. Pearson correlation test was used to test the hypotheses and linear regression analysis was used to investigate the relationship between the dependent and independent variables.

Table 3. The value and significant test for variables of rural tourism development and sustainable livelihoods

\begin{tabular}{|c|c|c|c|c|c|c|}
\hline \multicolumn{2}{|l|}{ Total Number } & $\begin{array}{l}\text { Rural } \\
\text { Tourism } \\
230 \\
\end{array}$ & $\begin{array}{l}\text { Sustainable } \\
\text { livelihood } \\
230\end{array}$ & $\begin{array}{l}\text { Economic } \\
\text { Structures } \\
230\end{array}$ & $\begin{array}{l}\text { Assets } \\
230 \\
\end{array}$ & $\begin{array}{l}\text { Vulnerability } \\
230\end{array}$ \\
\hline \multirow{2}{*}{$\begin{array}{l}\text { Normal } \\
\text { parameters }\end{array}$} & Average & 3.3816 & 30.8961 & 10.9304 & 15.3933 & 4.5723 \\
\hline & $\begin{array}{l}\text { standard } \\
\text { deviation }\end{array}$ & 0.42080 & 4.64455 & 1.88877 & 2.52329 & 0.83005 \\
\hline \multirow{3}{*}{$\begin{array}{l}\text { Most } \\
\text { differences }\end{array}$} & Invariable & 0.097 & 0.093 & 0.089 & 0.096 & 0.104 \\
\hline & Positive & 0.097 & 0.093 & 0.089 & 0.096 & 0.104 \\
\hline & Negative & -0.091 & -0.092 & -0.084 & -0.062 & -0.071 \\
\hline \multicolumn{2}{|c|}{ Test value (t-value) } & 0.097 & 0.093 & 0.089 & 0.096 & 0.104 \\
\hline
\end{tabular}




\begin{tabular}{llllll} 
Significance level & 0.076 & 0.193 & 0.119 & 0.591 & 0.219 \\
\hline \multirow{2}{*}{ Results } & normal & normal & normal & normal & normal \\
& distribution & distribution & distribution & distribution & distribution \\
\hline
\end{tabular}

\section{H1: Rural tourism development is effective on sustainable livelihoods in rural areas of Lavij.}

Pearson correlation test scores for two variables "rural tourism development" and "sustainable livelihoods" was 0.813 with a significant level of 0.000 . This means that there is a significant relationship between the two variables and so the third hypothesis is confirmed. The relationship between the two variables is shown in Table 4.

Table 4. Regression model of rural tourism development impact on sustainable livelihoods

\begin{tabular}{|c|c|c|c|c|c|c|c|}
\hline \multirow{3}{*}{$\begin{array}{l}\text { Input and Output } \\
\text { variables }\end{array}$} & Method & \multicolumn{2}{|c|}{ Output variable } & \multicolumn{2}{|c|}{ Input variable } & \multicolumn{2}{|l|}{ Model } \\
\hline & Simultaneous & \multicolumn{2}{|l|}{0} & \multicolumn{2}{|c|}{$\begin{array}{l}\text { Rural tourism } \\
\text { development }\end{array}$} & \multicolumn{2}{|l|}{1} \\
\hline & \multicolumn{7}{|c|}{$\begin{array}{l}\text { a. The dependent variable: sustainable livelihoods of Lavij rural } \\
\text { b. All input variables have been entered by Enter Method. }\end{array}$} \\
\hline \multirow[t]{3}{*}{ Model suitability } & $\begin{array}{l}\text { Multiple } \\
\text { correlation } \\
\text { coefficient }\end{array}$ & \multicolumn{2}{|c|}{$\begin{array}{l}\text { Coefficient } \\
\text { determination }\end{array}$} & \multicolumn{2}{|c|}{$\begin{array}{l}\text { Corrected } \\
\text { coefficient } \\
\text { determination }\end{array}$} & \multicolumn{2}{|c|}{$\begin{array}{l}\text { Standard } \\
\text { the estimate }\end{array}$} \\
\hline & 0.813 & \multicolumn{2}{|c|}{0.661} & \multicolumn{2}{|c|}{0.657} & \multicolumn{2}{|l|}{4.38959} \\
\hline & \multicolumn{7}{|c|}{$\begin{array}{l}\text { a. The dependent variable: Sustainable livelihood assets of Lavij } \\
\text { b. All input variables have been entered by Enter Method. }\end{array}$} \\
\hline \multirow{4}{*}{$\begin{array}{l}\text { Bivariate } \\
\text { regression } \\
\text { analysis }\end{array}$} & $\begin{array}{ll}\text { Source } & \text { of } \\
\text { variation }\end{array}$ & \multicolumn{2}{|c|}{ Sum of squares } & $\mathrm{Df}$ & $\begin{array}{l}\begin{array}{l}\text { Average of } \\
\text { squares }\end{array} \\
\end{array}$ & $\begin{array}{l}\text { F- } \\
\text { Quantity }\end{array}$ & $\begin{array}{l}\text { Significant } \\
\text { effects }\end{array}$ \\
\hline & $\begin{array}{l}\text { The effect } \\
\text { of regression }\end{array}$ & \multicolumn{2}{|l|}{546.722} & 1 & \multirow[t]{3}{*}{$\begin{array}{l}546.722 \\
19.269\end{array}$} & \multirow[t]{3}{*}{28.374} & \multirow[t]{3}{*}{ b $\quad 0.000$} \\
\hline & The remainder & \multirow{2}{*}{\multicolumn{2}{|c|}{4393.221}} & \multirow{2}{*}{\begin{tabular}{|l|l|}
228 \\
229 \\
\end{tabular}} & & & \\
\hline & Total & 4939.94 & & & & & \\
\hline \multirow{4}{*}{$\begin{array}{l}\text { Independent } \\
\text { variable } \\
\text { regression model }\end{array}$} & \multirow[t]{2}{*}{ variable } & \multicolumn{2}{|c|}{$\begin{array}{l}\text { Non-standard } \\
\text { coefficient }\end{array}$} & \multirow{2}{*}{\multicolumn{2}{|c|}{$\begin{array}{l}\text { Non-standard } \\
\text { coefficient } \\
\text { Beta }\end{array}$}} & \multirow[t]{2}{*}{$\mathrm{T}$} & \multirow[t]{2}{*}{ Sign } \\
\hline & & $\mathrm{B}$ & Std.Error & & & & \\
\hline & Fixed amount & 18.479 & 2.349 & \multirow{2}{*}{\multicolumn{2}{|c|}{0.813}} & 7.867 & 0.000 \\
\hline & $\begin{array}{l}\text { Rural tourism } \\
\text { development }\end{array}$ & 3.672 & 0.689 & & & 5.327 & 0.000 \\
\hline
\end{tabular}

The regression equation:

Sustainable livelihoods of Lavij $=($ rural tourism development $\times 1.598)+(9.990)$

Standard linear equation:

Sustainable livelihoods of Lavij $=($ rural tourism development $\times 0.748)$

According to the results, the independent variable (rural tourism development) can predict 66.1 per cent of sustainable livelihoods in Lavij. There is a direct linear relationship between independent and dependent variables. Also, rural tourism development variable with the 0.813 beta in the regression model, it's effective for the explanation of sustainable livelihoods in Lavij.

\section{H2: There is a significant relationship between the development of rural tourism and sustainable} livelihoods assets in Lavij rural.

Pearson correlation test scores for two variables "rural tourism development" and "sustainable livelihoods assets" were 0.748 with a significant level of 0.000 . This means that there is a significant relationship between the two variables and so the first hypothesis is confirmed. The test results related to the development of rural tourism relations between the different variables and sustainable livelihoods assets in Lavij's villages is shown in table 5 which generated the linear combination of independent variables and shows a maximum correlation with the dependent variable. 
Table 5. Regression model of rural tourism development impact on sustainable livelihoods assets

\begin{tabular}{|c|c|c|c|c|c|c|c|}
\hline \multirow{3}{*}{$\begin{array}{l}\text { Input and Output } \\
\text { variables }\end{array}$} & Method & \multicolumn{2}{|c|}{ Output variable } & \multicolumn{2}{|c|}{ Input variable } & \multicolumn{2}{|l|}{ Model } \\
\hline & Simultaneous & \multicolumn{2}{|l|}{0} & \multicolumn{2}{|c|}{$\begin{array}{l}\text { Rural tourism } \\
\text { development }\end{array}$} & \multicolumn{2}{|l|}{1} \\
\hline & \multicolumn{7}{|c|}{$\begin{array}{l}\text { a. The dependent variable: Sustainable livelihood assets of Lavij rural } \\
\text { b. All input variables have been entered by Enter Method. }\end{array}$} \\
\hline \multirow[t]{3}{*}{ Model suitability } & $\begin{array}{l}\text { Multiple } \\
\text { correlation } \\
\text { coefficient }\end{array}$ & \multicolumn{2}{|c|}{$\begin{array}{l}\text { Coefficient of } \\
\text { determination }\end{array}$} & \multicolumn{2}{|c|}{$\begin{array}{ll}\text { Corrected } & \\
\text { coefficient } \\
\text { determination }\end{array}$} & \multicolumn{2}{|c|}{$\begin{array}{l}\text { Standard error of } \\
\text { the estimate }\end{array}$} \\
\hline & 0.748 & \multicolumn{2}{|l|}{0.560} & \multicolumn{2}{|c|}{0.547} & \multicolumn{2}{|l|}{2.43739} \\
\hline & \multicolumn{7}{|c|}{$\begin{array}{l}\text { a. The dependent variable: Sustainable livelihood assets of Lavij } \\
\text { b. All input variables have been entered by Enter Method. }\end{array}$} \\
\hline \multirow{4}{*}{$\begin{array}{l}\text { Bivariate } \\
\text { regression } \\
\text { analysis }\end{array}$} & $\begin{array}{ll}\text { Source } & \text { of } \\
\text { variation }\end{array}$ & \multicolumn{2}{|c|}{ Sum of squares } & $\mathrm{Df}$ & $\begin{array}{l}\text { Average of } \\
\text { squares }\end{array}$ & $\begin{array}{l}\text { F- } \\
\text { Quantity }\end{array}$ & $\begin{array}{l}\text { Significant } \\
\text { effects }\end{array}$ \\
\hline & $\begin{array}{l}\text { The effect } \\
\text { of regression }\end{array}$ & \multicolumn{2}{|c|}{103.518} & 1 & \multirow{3}{*}{$\begin{array}{l}103.518 \\
5.941\end{array}$} & \multirow{3}{*}{17.425} & \multirow{3}{*}{0.000} \\
\hline & The remainder & \multicolumn{2}{|c|}{1354.521} & 228 & & & \\
\hline & Total & \multicolumn{2}{|c|}{1458.039} & 229 & & & \\
\hline \multirow{4}{*}{$\begin{array}{l}\text { Independent } \\
\text { variable } \\
\text { regression model }\end{array}$} & \multirow{2}{*}{ variable } & \multicolumn{2}{|c|}{$\begin{array}{l}\text { Non-standard } \\
\text { coefficient }\end{array}$} & \multicolumn{2}{|c|}{$\begin{array}{l}\text { Non-standard } \\
\text { coefficient }\end{array}$} & \multirow[t]{2}{*}{$\mathrm{T}$} & \multirow{2}{*}{ Sign } \\
\hline & & B & Std.Error & Beta & & & \\
\hline & Fixed amount & 9.990 & 1.304 & \multirow{2}{*}{\multicolumn{2}{|c|}{0.748}} & 7.659 & 0.000 \\
\hline & $\begin{array}{l}\text { Rural tourism } \\
\text { development }\end{array}$ & 1.598 & 0.383 & & & 4.174 & 0.000 \\
\hline
\end{tabular}

The regression equation:

Sustainable livelihood assets of Lavij $=($ rural tourism development $\times 1.598)+(9.990)$

Standard linear equation:

Sustainable livelihood assets of rural villages Lavij $=($ rural tourism development $\times 0.748)$

This linear combination can be used to predict the amount of sustainable livelihoods assets variable and the importance of rural tourism development variable on the sustainable livelihood assets variable in rural areas of Lavij. As the first entry, the development of rural tourism as an independent variable to predict the changes of dependent variable (sustainable livelihoods assets) were imported to the regression model at the same time. Based on the result, the independent variable has been able to predict $56 \%$ of the variability of sustainable livelihoods in rural areas of Lavij. The results show that the regression model is significant and fit. Being significance means between independent (rural tourism development) and dependent variables (sustainable livelihoods assets) is certainly a direct linear relationship. Also, rural tourism development variable with the beta 0.748 in the regression model, is effective in explanation of sustainable livelihoods assets in Lavij rural.

\section{H3: There is a significant relationship between rural tourism development and vulnerability of sustainable livelihoods in Lavij rural.}

Pearson correlation test scores for two variables "rural tourism development" and "vulnerability of sustainable livelihoods were 0.894 with a significant level of 0.000 . This means that there is a significant relationship between the two variables and so the second hypothesis is confirmed. Based on the results of the second hypothesis, the relationship between the rural tourism development and sustainable livelihoods vulnerability variables in Lavij rural shown in Table 6. 
Table 6. Regression model of rural tourism development impact on vulnerability of sustainable livelihoods

\begin{tabular}{|c|c|c|c|c|c|c|c|}
\hline \multirow{3}{*}{$\begin{array}{l}\text { Input and Output } \\
\text { variables }\end{array}$} & Method & \multicolumn{2}{|c|}{ Output variable } & \multicolumn{2}{|c|}{ Input variable } & \multicolumn{2}{|l|}{ Model } \\
\hline & Simultaneous & \multicolumn{2}{|l|}{0} & \multicolumn{2}{|c|}{$\begin{array}{l}\text { Rural tourism } \\
\text { development }\end{array}$} & \multicolumn{2}{|l|}{1} \\
\hline & \multicolumn{7}{|c|}{$\begin{array}{l}\text { a. The dependent variable: vulnerability of sustainable livelihoods in Lavij } \\
\text { b. All input variables have been entered by Enter Method. }\end{array}$} \\
\hline \multirow[t]{3}{*}{ Model suitability } & $\begin{array}{l}\text { Multiple } \\
\text { correlation } \\
\text { coefficient }\end{array}$ & \multicolumn{2}{|c|}{$\begin{array}{l}\text { Coefficient of } \\
\text { determination }\end{array}$} & \multicolumn{2}{|c|}{$\begin{array}{l}\text { Corrected } \\
\text { coefficient } \\
\text { determination }\end{array}$} & \multicolumn{2}{|c|}{$\begin{array}{l}\text { Standard } \\
\text { the estimate }\end{array}$} \\
\hline & 0.894 & \multicolumn{2}{|l|}{0.799} & \multicolumn{2}{|c|}{0.784} & \multicolumn{2}{|l|}{0.79513} \\
\hline & \multicolumn{7}{|c|}{$\begin{array}{l}\text { a. The dependent variable: vulnerability of sustainable livelihoods in Lavij } \\
\text { b. All input variables have been entered by Enter Method. }\end{array}$} \\
\hline \multirow{4}{*}{$\begin{array}{l}\text { Bivariate } \\
\text { regression } \\
\text { analysis }\end{array}$} & $\begin{array}{l}\text { Source of } \\
\text { variation }\end{array}$ & \multicolumn{2}{|c|}{ Sum of squares } & Df & $\begin{array}{l}\text { Average of } \\
\text { squares }\end{array}$ & $\begin{array}{l}\text { F- } \\
\text { Quantity }\end{array}$ & $\begin{array}{l}\text { Significant } \\
\text { effects }\end{array}$ \\
\hline & $\begin{array}{l}\text { The effect } \\
\text { of regression }\end{array}$ & \multicolumn{2}{|c|}{13.628} & 1 & \multirow[t]{3}{*}{$\begin{array}{l}13.628 \\
0.632\end{array}$} & \multirow[t]{3}{*}{21.556} & \multirow[t]{3}{*}{$\begin{array}{ll}\mathrm{b} & 0.000\end{array}$} \\
\hline & The remainder & \multicolumn{2}{|c|}{144.149} & 228 & & & \\
\hline & Total & \multicolumn{2}{|c|}{157.777} & 229 & & & \\
\hline \multirow{4}{*}{$\begin{array}{l}\text { Independent } \\
\text { variable } \\
\text { regression model }\end{array}$} & \multirow[t]{2}{*}{ variable } & \multicolumn{2}{|c|}{$\begin{array}{l}\text { Non-standard } \\
\text { coefficient }\end{array}$} & \multirow{2}{*}{\multicolumn{2}{|c|}{$\begin{array}{l}\text { Non-standard } \\
\text { coefficient } \\
\text { Beta }\end{array}$}} & \multirow[t]{2}{*}{$\mathrm{T}$} & \multirow[t]{2}{*}{ Sign } \\
\hline & & $\mathrm{B}$ & Std.Error & & & & \\
\hline & Fixed amount & 2.612 & 0.425 & \multirow{2}{*}{\multicolumn{2}{|c|}{0.894}} & 6.138 & 0.000 \\
\hline & $\begin{array}{l}\text { Rural tourism } \\
\text { development }\end{array}$ & 0.580 & 0.125 & & & 4.643 & 0.000 \\
\hline \multicolumn{8}{|c|}{$\begin{array}{l}\text { The regression equation: } \\
\text { vulnerability of sustainable livelihoods in Lavij }=(\text { rural tourism development } \times 1.598)+(9.990) \\
\text { Standard linear equation: } \\
\text { vulnerability of sustainable livelihoods in Lavij }=(\text { rural tourism development } \times 0.748)\end{array}$} \\
\hline
\end{tabular}

According to the results of the model, the independent variable (rural tourism development) can predict 79.9 per cent of the vulnerability of rural sustainable livelihoods in Lavij. There is a direct linear relationship between the independent variable (rural tourism development) and the dependent variable (the vulnerability of rural sustainable livelihoods). Also, rural tourism development variable with the 0.894 beta in the regression model, it's effective for the explanation of the vulnerability of rural sustainable livelihoods in Lavij.

\section{H4: There is a significant relationship between rural tourism development and rural economic structures of sustainable livelihoods in Lavij.}

Pearson correlation test score for two variables "rural tourism development" and "rural economic structures of sustainable livelihoods" was 0.733 with a significant level of 0.000 . This means that there is a significant relationship between the two variables and so the third hypothesis is confirmed. The relationship between the two variables is shown in Table 7 .

Table 7. Regression model of rural tourism development impact on rural economic structures of sustainable livelihoods in Lavij

\begin{tabular}{|c|c|c|c|c|}
\hline \multirow{3}{*}{$\begin{array}{l}\text { Input and Output } \\
\text { variables }\end{array}$} & Method & Output variable & Input variable & Model \\
\hline & Simultaneous & 0 & $\begin{array}{l}\text { Rural tourism } \\
\text { development }\end{array}$ & 1 \\
\hline & \multicolumn{4}{|c|}{$\begin{array}{l}\text { a. The dependent variable: Rural economic structures of sustainable livelihoods in Lavij } \\
\text { b. All input variables have been entered by Enter Method. }\end{array}$} \\
\hline \multirow[t]{3}{*}{ Model suitability } & $\begin{array}{l}\text { Multiple } \\
\text { correlation } \\
\text { coefficient }\end{array}$ & $\begin{array}{l}\text { Coefficient } \\
\text { determination }\end{array}$ & $\begin{array}{l}\text { Corrected } \\
\text { coefficient } \\
\text { determination }\end{array}$ & $\begin{array}{l}\text { Standard } \\
\text { the estimate }\end{array}$ \\
\hline & 0.733 & 0.537 & 0.531 & 1.78491 \\
\hline & \multicolumn{4}{|c|}{ a. The dependent variable: Rural economic structures of sustainable livelihoods in Lavij } \\
\hline
\end{tabular}




\begin{tabular}{|c|c|c|c|c|c|c|c|}
\hline & \multicolumn{7}{|c|}{ b. All input variables have been entered by Enter Method. } \\
\hline \multirow{4}{*}{$\begin{array}{l}\text { Bivariate } \\
\text { regression } \\
\text { analysis }\end{array}$} & $\begin{array}{ll}\text { Source } \\
\text { variation }\end{array}$ & \multicolumn{2}{|c|}{ Sum of squares } & Df & $\begin{array}{l}\text { Average of } \\
\text { squares }\end{array}$ & $\begin{array}{l}\text { F- } \\
\text { Quantity }\end{array}$ & $\begin{array}{l}\text { Significant } \\
\text { effects }\end{array}$ \\
\hline & $\begin{array}{l}\text { The effect } \\
\text { of regression }\end{array}$ & \multicolumn{2}{|c|}{90.556} & 1 & \multirow[t]{3}{*}{$\begin{array}{l}90.556 \\
3.186\end{array}$} & \multirow[t]{3}{*}{28.424} & \multirow[t]{3}{*}{$\begin{array}{ll}\mathrm{b} & 0.000\end{array}$} \\
\hline & The remainder & \multirow{2}{*}{\multicolumn{2}{|c|}{$\begin{array}{l}726.378 \\
816.943\end{array}$}} & 228 & & & \\
\hline & Total & & & 229 & & & \\
\hline \multirow{4}{*}{$\begin{array}{l}\text { Independent } \\
\text { variable } \\
\text { regression model }\end{array}$} & \multirow[t]{2}{*}{ variable } & \multicolumn{2}{|c|}{$\begin{array}{l}\text { Non-standard } \\
\text { coefficient }\end{array}$} & \multicolumn{2}{|c|}{$\begin{array}{l}\text { Non-standard } \\
\text { coefficient } \\
\text { Beta }\end{array}$} & \multirow[t]{2}{*}{$\mathrm{T}$} & \multirow[t]{2}{*}{ Sign } \\
\hline & & $\mathrm{B}$ & Std.Error & Beta & & & \\
\hline & Fixed amount & 5.887 & 0.955 & \multirow{2}{*}{\multicolumn{2}{|c|}{0.733}} & 6.153 & 0.000 \\
\hline & $\begin{array}{l}\text { Rural tourism } \\
\text { development }\end{array}$ & 1.494 & 0.280 & & & 5.331 & 0.000 \\
\hline
\end{tabular}

The regression equation:

Rural economic structures of sustainable livelihoods in Lavij $=($ rural tourism development $\times 1.598)+(9.990)$

Standard linear equation:

Rural economic structures of sustainable livelihoods in Lavij= (rural tourism development $\times 0.748)$

According to the results, the independent variable (rural tourism development) can predict 53.7 per cent of the rural economic structures of sustainable livelihoods in Lavij. There is a direct linear relationship between the independent and dependent variables. Also, rural tourism development variable with the 0.733 beta in the regression model, it's effective for the explanation of the vulnerability of rural economic structures of sustainable livelihoods in Lavij.

\section{Discussion}

The main purpose of this study was to evaluate the effect of rural tourism development on the Lavij's people's life and livelihood. According to the obtained results, rural tourism has a great impact on sustainable livelihood of indigenous people. For many years, rural tourism was implicated as a strategy towards development for rural areas (Heikkilä, Poladova, \& Kääriä, 2014). From fishing in Norway to farming in West America, all are baits to attract tourists to rural areas (Macdonald \& Jolliffe, 2003). Development of Rural tourism by diversification of the local economy will boost the quality of life for that region and improve infrastructures like transportation system (Fleischer \& Felsenstein, 2000). Thus there is a need for a systematic and long-term planning to develop rural tourism in Lavij. As well, it is essential for local people to get involved in the planning process. So the programs become compatible with the sustainable development process (Garrod, Wornell, \& Youell, 2006).

The findings also demonstrated that the development of rural tourism has an impact on sustainable livelihood assets. For developing rural tourism, the main attractions must be maintained and kept in good condition (Jenny Briedenhann \& Wickens, 2004; Barke \& Wiley, 2004). Nature, customs and rituals of local people must stay unharmed from possible damages that tourism might bring to them. Also, old houses and places that could be considered as an attraction must be under protection.

This study also illustrate that there is a correlation between the rural tourism development and vulnerability of sustainable livelihood in Lavij. This means that tourism will reduce people vulnerability against economic fluctuations by creating job opportunities, rising incomes (Wilson et al., 2001; Park \& Yoon, 2009).

Also by proving the final hypothesis of this study, it is clear that there is a correlation between rural tourism development and the economic structure of sustainable livelihood in Lavij. Rural tourism development presents new opportunities for growth to local people by improving the flow of money in the villages (Lane, 1994) and creates a new market for their handmade merchandises. Due to the seasonality of the tourism industry, it is necessary for people in charge to define the economic structures in a way that with the change on the number of tourists in different seasons, local people's income does not damage as much (Fleischer \& Tchetchik, 2005).

\section{References}

Abinama, A., \& Jafari, M. (2015). The impact of the design of hospitals on hospital hoteling, healing process and medical tourism. Modern Applied Science, 9(12), 43-51. http://dx.doi.org/10.5539/mas.v9n12p43

Addinsall, C., Glencross, K., Scherrer, P., Weiler, B., \& Nichols, D. (2015). Agroecology and sustainable rural livelihoods: A Conceptual framework to guide development projects in the pacific islands. Agroecology and 
Sustainable Food Systems, 39(6), 691-723. http://dx.doi.org/10.1080/21683565.2015.1017785

Analysis of urbanization and internal migration situation in the Islamic Republic of Iran. (2012). Tehran. Retrieved from http://iran.unfpa.org/Index.asp

Ashley, C. (2000). The impacts of tourism on rural livelihoods: Namibia's experience. Overseas Development Institute. London.

Barke, M., \& Wiley, J. (2002). Rural tourism in Spain. Annals of Tourism Research, 29(4), 1101-1110. http://dx.doi.org/10.1002/jtr.480

Bhandari, P. B. (2013). Rural livelihood change? Household capital, community resources and livelihood transition. Journal of Rural Studies, 32, 126-136. http://dx.doi.org/10.1016/j.jrurstud.2013.05.001

Bidoki, M. Z., \& Kargar, M. J. (2016). A social cloud computing: Employing a Bee Colony Algorithm for sharing and allocating tourism resources. Modern Applied Science, 10(5), 177-185. http://dx.doi.org/10.5539/mas.v10n5p177

Binns, T., \& Nel, E. (2002). Tourism as a local development strategy in South Africa. The Geographical Journal, 168(3), 235-247.

Briedenhann, J., \& Wickens, E. (2004). Rural tourism - Meeting the challenges of the new South Africa. International Journal of Tourism Research, 6(3), 189-203. http://dx.doi.org/10.1002/jtr.484

Briedenhann, J., \& Wickens, E. (2004). Tourism routes as a tool for the economic development of rural areas-vibrant hope or impossible dream? Tourism Management, 25, 71-79. http://dx.doi.org/10.1016/S0261-5177(03)00063-3

Canoves, G., Villarino, M., Priestley, G. K., \& Blanco, A. (2004). Rural tourism in Spain: An analysis of recent evolution. Geoforum, 35(6 SPEC.ISS.), 755-769. http://dx.doi.org/10.1016/j.geoforum.2004.03.005

Christensen, A. E., \& Mertz, O. (2010). Researching Pacific island livelihoods: Mobility, natural resource management and nissology. Asia Pacific Viewpoint, 51(3), 278-287. http://dx.doi.org/10.1111/j.1467-8373.2010.01431.x

Dernoi, L. A. (1991). Prospects of rural tourism: Needs and opportunities. Tourism Recreation Research, 16(1), 89-94. http://dx.doi.org/10.1080/02508281.1991.11014615

Detailed results of the general census of agriculture. (2013). Tehran: Iran's statistic center.

Euromonitor. (2015). Passport: travel and tourism in Iran.

Evans, N. J., \& Ilbery, B. W. (1989). A conceptual framework for investigating farm-based accommodation and tourism in Britain. Journal of Rural Studies, 5(3), 257-266. http://dx.doi.org/10.1016/0743-0167(89)90004-1

Farmaki, A. (2012). An exploration of tourist motivation in rural settings: The case of Troodos, Cyprus. Tourism Management Perspectives, 2-3, 72-78. http://dx.doi.org/10.1016/j.tmp.2012.03.007

Fleischer, A., \& Felsenstein, D. (2000). Support of rural tourism: Does it make a difference? Annals of Tourism Research, 27(4), 1007-1024. http://dx.doi.org/10.1016/S0160-7383(99)00126-7

Fleischer, A., \& Pizamt, A. (1997). Rural tourism in Israel. Tourism Management, 18(6), 367-372. http://dx.doi.org/10.1016/S0261-5177(97)00034-4

Fleischer, A., \& Tchetchik, A. (2005). Does rural tourism benefit from agriculture? Tourism Management, 26(4), 493-501. http://dx.doi.org/10.1016/j.tourman.2003.10.003

Forstner, K. (2004). Community ventures and access to markets: The role of intermediaries in marketing rural tourism products. Development Policy Review, 22(5), 497-514. http://dx.doi.org/10.1111/j.1467-7679.2004.00262.x

Fotiadis, A., Yeh, S., \& Huan, T. T. C. (2016). Applying configural analysis to explaining rural-tourism success recipes. Journal of Business Research, 69(4), 1479-1483. http://dx.doi.org/10.1016/j.jbusres.2015.10.128

Friedman, J. (1992). Empowerment: The politics of an alternative development. Oxford: Wiley-Blackwell.

Garrod, B., Wornell, R., \& Youell, R. (2006). Re-conceptualising rural resources as countryside capital: The case of rural tourism. Journal of Rural Studies, 22, 117-128. http://dx.doi.org/10.1016/j.jrurstud.2005.08.001

Getz, D. (1983). Capacity to absorb tourism: Concepts and implications for strategic planning. Annals of Tourism Research, 10(2), 239-263. http://dx.doi.org/10.1016/0160-7383(83)90028-2 
Getz, D., \& Carlsen, J. (2000). Characteristics and goals of family and owner-operated businesses in the rural tourism and hospitality sectors. Tourism Management, 21, 547-560. http://dx.doi.org/10.1016/S0261-5177(00)00004-2

Ghaderi, Z., \& Henderson, J. C. (2012). Sustainable rural tourism in Iran: A perspective from Hawraman Village. Tourism Management Perspectives, 2-3, 47-54. http://dx.doi.org/10.1016/j.tmp.2012.03.001

Ghasemi Ardahani, A. (2006). Review the causes of Iranian rural migration to cities with meta-analysis of universities' theses (From 1980 to 2004). Rural andDevelopment, 9(1), 51-80.

Guerrero, G. G., Valdez Pérez, M. E., \& Ibarra, R. M. (2013). Community involvement in the assessment of the importance of sustainable rural tourism indicators for protected areas: The case of the Nevado de Toluca National Park in Mexico. WIT Transactions on Ecology and the Environment, 173, 417-428. http://dx.doi.org/10.2495/SDP130351

Guzman-parra, V. F., Quintana-garcía, C., Benavides-velasco, C. A., \& Vila-oblitas, J. R. (2015). Trends and seasonal variation of tourist demand in Spain: The role of rural tourism. Tourism Management Perspectives, 16, 123-128. http://dx.doi.org/10.1016/j.tmp.2015.07.014

Heikkilä, J., Poladova, A., \& Käärï, J. (2014). Need for service design development for sustainable rural tourism in Azerbaijan. Baltic Journal of European Studies, 4(2), 83-98. http://dx.doi.org/10.2478/bjes-2014-0017

Iorio, M., \& Corsale, A. (2010). Rural tourism and livelihood strategies in Romania. Journal of Rural Studies, 26, 152-162. http://dx.doi.org/10.1016/j.jrurstud.2009.10.006

Iran's domestic migration. (2011). Tehran: Iran's statistic center.

$\begin{array}{lllll}\text { Iran's } & \text { Statistics } & \text { Centre. } & \text { (2016). } & \text { Retrieved }\end{array}$ http://www.amar.org.ir/Portals/0/Files/baravord/b_ostani_85-95.xls

Jaafar, M., Bakri, N. M., \& Rasoolimanesh, S. M. (2015). Local community and tourism development: A study of rural mountainous destinations. Modern Applied Science, 9(8), 399-408. http://dx.doi.org/10.5539/mas.v9n8p407

Kheiri, J., Zeinabad, R. S., \& Tabatabaie, F. (2016). Evaluation of tourism investment priorities in Zoroastrian Villages of Yazd Province, Iran. American Journal of Rural Development, 4(1), 1-9. http://dx.doi.org/10.12691/ajrd-4-1-1

Kim, S., \& Jamal, T. (2015). The co-evolution of rural tourism and sustainable rural development in Hongdong, Korea: complexity, conflict and local response. Journal of Sustainable Tourism, 23(8-9). http://dx.doi.org/10.1080/09669582.2015.1022181

Lane, B. (1994). What is rural tourism? Journal of Sustainable Tourism, 2(1-2), 7-21. http://dx.doi.org/10.1080/09669589409510680

León, Y. M. (2007). The impact of tourism on rural livelihoods in the Dominican Republic's coastal areas. Journal of Development Studies, 43(2), 340-359. http://dx.doi.org/10.1080/00220380601125214

Li, P., Ryan, C., \& Cave, J. (2016). Chinese rural tourism development: Transition in the case of Qiyunshan , Anhui . - 2008 e 2015. Tourism Management, 55, 240-260. http://dx.doi.org/10.1016/j.tourman.2016.02.007

Luloff, A. E., Bridger, J. C., Graefe, A. R., Saylor, M., Martin, K., \& Gitelson, R. (1994). Assessing rural tourism efforts in the United States. Annals of Tourism Research, 21(1), 46-64. http://dx.doi.org/10.1016/0160-7383(94)90004-3

Macdonald, R., \& Jolliffe, L. (2003). Cultural rural tourism: Evidence from Canada. Annals of Tourism Research, 30(2), 307-322. http://dx.doi.org/10.1016/S0160-7383(02)00061-0

Maloletko, A. N., Kaurova, O. V., Kryukova, E. M., Pochinok, N. B., \& Gladko, E. A. (2015). Analysis of key indicators of tourism industry in Russia. Modern Applied Science, 9(3), 25-33. http://dx.doi.org/10.5539/mas.v9n3p25

Marsden, T. (1992). Exploring a rural scociology for the fordist transition: Incorporating social relations into economic restructuring. Sociologia Ruralis, 32(2/3), 209-230.

Mbaiwa, J. E., \& Kolawole, O. D. (2013). Tourism and biodiversity conservation: the case of community-based natural resource management in Southern Africa. CAB Reviews, $8(010)$. http://dx.doi.org/10.1079/PAVSNNR20138010 
Mcareavey, R., \& Mcdonagh, J. (2011). Sustainable rural tourism: Lessons for rural development. Sociologia Ruralis, 51(2), 175-194. http://dx.doi.org/10.1111/j.1467-9523.2010.00529.x

Möller, C. (2012). Gendered entrepreneurship in rural Latvia: Exploring femininities, work, and livelihood within rural tourism. Journal of Baltic Studies, 43(1), 75-94. http://dx.doi.org/10.1080/01629778.2011.634103

Moosa Dokht, A. (2013). The role of ecotourism in watershed management (case studies: Lavij Watershed, Nur). Azad university of Nur.

Oppermann, M. (1996). Rural tourism in Southern Germany. Annals of Tourism Research, 23(1), 86-102. http://dx.doi.org/10.1016/0160-7383(95)00021-6

Park, D., \& Yoon, Y. (2009). Segmentation by motivation in rural tourism: A Korean case study. Tourism Management, 30, 99-108. http://dx.doi.org/10.1016/j.tourman.2008.03.011

Park, D.-B., Lee, K.-W., Choi, H.-S., \& Yoon, Y. (2012). Factors influencing social capital in rural tourism communities in South Korea. Tourism Management, 33, 1511-1520. http://dx.doi.org/10.1016/j.tourman.2012.02.005

Place, S. E. (1991). Nature tourism and rural development in Tortuguero. Annals of Tourism Research, 18(2), 186-201. http://dx.doi.org/10.1016/0160-7383(91)90003-T

Reichel, A., Lowengart, O., \& Milman, A. (2000). Rural tourism in Israel: Service quality and orientation. Tourism Management, 21(5), 451-459. http://dx.doi.org/10.1016/S0261-5177(99)00099-0

Rid, W., Ezeuduji, I. O., \& Pröbstl-Haider, U. (2014). Segmentation by motivation for rural tourism activities in The Gambia. Tourism Management, 40, 102-116. http://dx.doi.org/10.1016/j.tourman.2013.05.006

Silva, L., \& Leal, J. (2015). Rural tourism and national identity building in contemporary Europe: Evidence from Portugal. Journal of Rural Studies, 38, 109-119. http://dx.doi.org/10.1016/j.jrurstud.2015.02.005

Tourism highlight. (2015). United Nations World Tourism Organization (UNWTO).

Travel \& tourism economic impact: Iran. (2015). The World Travel \& Tourism Council (WTTC).

Turnock, D. (1990). Tourism in Romania: Rural planning in the Carpathians. Annals of Tourism Research, 17(1), 79-102. http://dx.doi.org/10.1016/0160-7383(90)90116-9

UNESCO. (2016). Retrieved from http://whc.unesco.org/en/statesparties/ir

Wahab, S. (1974). Elements of state policy on tourism. Torino. Turin: Italgraphica.

Wilson, S., Fesenmaier, D. R., Fesenmaier, J., \& Es, J. C. Van. (2001). Factors for success in rural tourism development. Journal of Travel Research, 40, 132-138. http://dx.doi.org/10.1177/004728750104000203

Zhou, L. (2014). Online rural destination images: Tourism and rurality. Journal of Destination Marketing and Management, 3(4), 227-240. http://dx.doi.org/10.1016/j.jdmm.2014.03.002

Note

Note 1. Small and medium-sized enterprises.

Note 2. Toman is the official currency of Iran. Each 1000 Tomans equal to 0.28 USD.

\section{Copyrights}

Copyright for this article is retained by the author(s), with first publication rights granted to the journal.

This is an open-access article distributed under the terms and conditions of the Creative Commons Attribution license (http://creativecommons.org/licenses/by/3.0/). 